\title{
PORUŠENÍ PÉČE ŘÁDNÉHO HOSPODÁŘE - SUBJEKTIVNÍ, NEBO OBJEKTIVNÍ ODPOVĚDNOST ZA ŠKODU?
}

\author{
TOMÁŠ CHRENEK
}

Abstract: Breach of Due Managerial Care - Subjective or Objective Liability for Damage?

This article deals with the legal basis of due managerial care, whose nature determines the rules applied in case of a breach of due managerial care concerning damages.

The article summarizes recent professional discussions on the topic and deals with three major theoretical approaches defining due managerial care either as an obligation from law, or an obligation from contract, or an obligation sui generis.

The article discuses arguments for and against each approach, puts forward the author's critics regarding the mentioned discourses, and brings the author's own look at the problem, the key point of which is the necessary consistency of a conclusion not only for a statutory body, but also for other elected bodies of a legal person.

Keywords: damages; member of a body; due managerial care

Klíčová slova: škoda; člen orgánu; péče řádného hospodáře

DOI: $10.14712 / 23366478.2021 .32$

\section{ÚVOD DO TÉMATU}

Nový občanský zákoník terminologicky opustil koncepci „odpovědnosti“‘1 za škodu užívanou do konce roku 2013 zákonem č. 40/1964 Sb., občanský zákoník. Aktuálně účinný občanský zákoník v celém dílu 1. hlavy III. části čtvrté o náhradě majetkové a nemajetkové újmy ani jedinkrát nepracuje s pojmem „odpovědnost“", nýbrž výlučně s pojmem ,povinnosti“ (nahradit škodu). Z toho je patrný důraz právní úpravy toliko na vznik závazku, přičemž pouhá deklarace „odpovědnosti“ bez vzniku právního následku - závazku - by neměla další právní relevanci.

Za zavádějící považuji nadpis hlavy III. části čtvrté jako „Závazky z deliktư“, kterýžto pojem není z jazykového hlediska přiléhavý pro vznik odpovědnosti bez zavinění škůdce ve smyslu § 2895 občanského zákoníku (objektivní odpovědnost). Hrádek² pak

1 Srov. nadpis části šesté zákona č. 40/1964 Sb., občanský zákoník, ve znění účinném do 31. 12. 2013.

2 HRÁDEK, J. Komentář k § 2894. In: ŠVESTKA, J. - DVOŘÁK, J. - FIALA, J. a kol. Občanský zákoník: komentár. Svazek VI, (\$ 2521-3081): relativni majetková práva. 2. část. Praha: Wolters Kluwer, 2014. In: ASPI [online]. [cit. 2021-03-14]. 
považuje použití pojmu „delikt“ vůbec za významnou nekoncepčnost s tím, že se občanský zákoník odklání od římskoprávního (kontinentálního) chápání pojmu deliktu jako porušení zákona k chápání pojmu deliktu jako porušení jakékoli soukromoprávní povinnosti, což je př́iznačné spíše pro anglosaské právní prostředí.

Ve smyslu římskoprávní nauky se př́ípady povinnosti nahradit škodu za současné absence zavinění povinného řadí mezi tzv. „kvazidelikty“. ${ }^{3} \mathrm{~V}$ tomto světle by bylo lze dovozovat, že zákonodárce pro zjednodušení řadí do hlavy s názvem „Závazky z deliktư“ “ jak delikty, tak kvazidelikty, $\mathrm{k}$ vysvětlení čehož může sloužit právě citovaný $\S 2895$. Je-li tomu tak, potom s takovým záměrem není konzistentní skutečnost, že jiný „kvazidelikt" , ${ }^{4}$ konkrétně bezdůvodné obohacení, občanský zákoník řadí do samostatné hlavy IV. části čtvrté jako „závazek z jiných právních důvodů“.

Nový občanský zákoník tedy ve věci odpovědnostní problematiky není terminologicky jednoznačný.

Ke vzniku povinnosti nahradit škodu je třeba naplnit některou ze skutkových podstat hlavy III. části čtvrté občanského zákoníku. Bylo by chybou uzavř́it, že povinnost člena orgánu společnosti k náhradě škody způsobené společnosti vyplývá toliko z § 159 odst. 1 občanského zákoníku o péči řádného hospodáře. Vzhledem $\mathrm{k}$ tomu, že v odborné veřejnosti nepanuje shoda na tom, jaký je právní důvod vzniku povinnosti jednat s péči ráádného hospodáře, konkrétně zda se jedná o povinnost ze zákona, ze smlouvy, či zvláštní důvod sui generis, nepanuje logicky ani shoda na tom, pod jakou deliktní skutkovou podstatu podřadit porušení této povinnosti. Toto podřazení přitom může mít zásadní význam, nebot' ke vzniku povinnosti nahradit škodu způsobenou porušením zákona se vyžaduje zavinění škůdce (subjektivní odpovědnost), zatímco v př́ípadě porušení smlouvy nikoli5 (objektivní odpovědnost). Ohledně tohoto problému probíhá posledních několik let poměrně hojná odborná diskuse, do níž se zapojuji níže uvedeným textem.

\section{PÉČE ŘÁDNÉHO HOSPODÁŘE JAKO POVINNOST ZE ZÁKONA}

K povaze péče řádného hospodáře jakožto zákonné povinnosti se jednoznačně kloní Dvořák ${ }^{6} \mathrm{~s}$ odůvodněním, že právní poměr mezi právnickou osobou a členem voleného orgánu vzniká ze zákona dnem vzniku funkce člena voleného orgánu, a nemůže tedy jít o odpovědnost za porušení smluvní povinnosti podle $§ 2913$ občanského zákoníku. Nedostatkem tohoto argumentu je ztotožnění (bez dalšího) právního důvodu vzniku funkce s právním důvodem povinnosti jednat s péči ráádného hospodáře, ačkoli povinnost péče řádného hospodáře je pouze dílčím (nikoli vyčerpávajícím) aspektem právního vztahu mezi právnickou osobou a členem jejího voleného orgánu,

\footnotetext{
KINCL, J. - URFUS, V. - SKŘEJPEK, M. Řimské právo. 2. vyd. Praha: C. H. Beck, 1995, s. 265.

Viz např. usnesení Nejvyššího soudu ze dne 12. 3. 2014, sp. zn. 28 Cdo 2953/2013.

K tomu blíže např. BEZOUŠKA, P. § 2913. In: HULMÁK, M. a kol. Občanský zákonik. VI., Závazkové právo: zvláštní ćást (\$ 2055-3014). Praha: C. H. Beck, 2014, s. 1565.

6 DVOŘÁK, T. Komentář k § 159. In: ŠVESTKA, J. Občanský zákoník: komentářr. 2. vyd. Praha: Wolters Kluwer ČR, 2019. In: ASPI [online]. [cit. 2021-03-14].
} 
jehož součástí může být řada dalších vzájemných práv a povinností, např. zákaz konkurence člena orgánu, ${ }^{7}$ povinnost právnické osoby platit členovi právnické osoby odměnu za výkon funkce atd. Navíc zcela opomíjí právní jednání volitele a přijetí funkce ze strany voleného, resp. otázku, zda lze tyto úkony považovat za ofertu a akceptaci sui generis směrující ke vzniku závazku. Časové hledisko, tedy určení okamžiku, kdy právní poměr mezi právnickou osobou a členem orgánu vzniká, nepovažuji za aspekt, který by mohl vnést do řešené otázky světlo.

Mnohem podrobnější analýzu problému provádí Novotná Krtoušová, ${ }^{8}$ která k řešení přistupuje skrze druh zastoupení, resp. skrze otázku, zda zastoupení právnické osoby je zastoupením zákonným, či smluvním. Autorka dovozuje, že zastoupení právnické osoby členem statutárního orgánu je zastoupením zákonným, proto i odpovědnost za jednání s péčí rádného hospodáře bude sankcionováno povinností $\mathrm{k}$ náhradě škody za porušení zákonné povinnosti dle $\S 2910$ občanského zákoníku. Hlavním nedostatkem předestřeného řešení je redukce problému na statutární orgán a zároveň na právní jednání jménem jiného ve smyslu $\S 436$ a násl. občanského zákoníku. Závěry o povaze zastoupení lze však mnohem tíže aplikovat na jiné volené orgány právnických osob než statutární, zejména pak zákonem neupravené (např. auditor účtu spolku), které nemají oprávnění v zastoupení právnické osoby hmotně právně ani procesně jednat. I pokud připustíme, že takový vyloženě ,interní“ orgán právnické osoby právnickou osobu $z a$ stupuje a určitým způsobem nahrazuje vůli této právnické osoby, byt' v omezeném rozsahu, např. pouze ve vztahu ke členům orgánu statutárního, pak zcela jistě nemůžeme bez dalšího uzavř́ít, že se jedná o zastupování ze zákona. Naopak se lze domnívat, že takové „zastupování“ těmito fakultativními, zákonem neupravenými orgány, by mělo blíže spíše ke smluvní podstatě. Ze shora uvedených důvodů se nedomnívám, že otázka deliktní skutkové podstaty při porušení péče řádného hospodáře by nalezla řešení skrze typ zastoupení právnické osoby statutárním orgánem. Bezpochyby však tento př́stup přináší do diskuse zajímavé podněty.

Zásadním argumentem ve prospěch zákonné podstaty povinnosti péče řádného hospodáře je kogentnost této povinnosti. ${ }^{9}$ Jestliže by právní důvod vzniku povinnosti jednat s péči řádného hospodáře byl smluvní povahy, pak by ji mělo být možné v souladu s podstatou smlouvy jakožto autonomního projevu vůle upravit, a to alespoň v nějakém minimálním rozsahu, což tak ovšem není. O otázce dispozitivnosti či kogentnosti § 159 občanského zákoníku sice odborná veřejnost nezř́íka pojednává, ${ }^{10}$ nicméně mi není znám žádný odborný závěr, který by se nakonec vyjádřil ve prospěch dispozitivnosti. $\mathrm{V}$ př́padě obchodních korporací lze zmiňovanou kogentnost dovozovat zejm. z $§ 53$ odst. 2 ZOK. V př́padě právnických osob obecně lze pak kogentnost dovozovat zejm.

\footnotetext{
7 Např. $\S 441$ ZOK.

8 NOVOTNÁ KRTOUŠOVÁ, L. Odpovědnost za jednání s péčí řádného hospodáře z pohledu teorií právnických osob. Časopis pro právni vědu a praxi. 2020, roč. 28, č. 2, s. 247-266.

9 Shodně LASÁK, J. Komentář k § 51. In: LASÁK, J. - POKORNÁ, J. - ČÁP Z. - DOLEŽIL, T. a kol. Zákon o obchodních korporacích: komentář. Praha: Wolters Kluwer, 2014. In: ASPI [online]. [cit. 2021-03-14].

10 Tamtéž.
} 
ze statusové povahy ${ }^{11}$ povinnosti péče rrádného hospodáře, od níž se ve smyslu $§ 1$ odst. 2 občanského zákoníku odchýlit nelze.

V poslední době lze v odborné diskusi spatřovat spíše odklon od argumentů zákonného pojetí péče řádného hospodáre směrem $\mathrm{k}$ její povaze jakožto povinnosti sui generis (viz níže). ${ }^{12}$

\section{PÉČE ŘÁDNÉHO HOSPODÁŘE JAKO SMLUVNÍ POVINNOST}

Smluvní důvod povinnosti péče rádného hospodáře deklaruje Svejkovský 13 s poukazem na skutečnost, že proti sobě stojí dvě právní jednání, na straně jedné akt volby, jmenování či jiného povolání osoby do funkce, na straně druhé přijetí funkce ze strany této osoby. Nedostatek tohoto argumentu je vlastně totožný s tím, který popisuji u Dvořáka ${ }^{14}$ výše, a sice ztotožnění povinnosti péče řádného hospodáře s právním vztahem mezi členem voleného orgánu a společností, kterýžto má ovšem bezpochyby širší rozměr, než je samotná povinnost jednat s péčí rádného hospodáře.

Přesvědčivější argument předkládá Lasák, ${ }^{15}$ který právní vztah mezi právnickou osobou a členem voleného orgánu s povinností péče rádného hospodáře neztotožňuje, ale považuje ji za imanentní součást tohoto vztahu. Právnická osoba a člen voleného orgánu mohou uzavř́t smlouvu konkretizující jejich vzájemná práva a povinnosti (smlouvu o výkonu funkce). V takovém př́padě dle názoru citovaného autora ,,[n]ení proto žádného důvodu, aby porušení těchto výslovně stanovených smluvních povinností mělo mít z hlediska náhrady škody odlišný režim oproti porušení péče řádného hospodáre, která je imanentni součástí smluvního vztahu mezi právnickou osobou a členem voleného orgánu, který je v důsledku vzniku funkce založen ". ${ }^{16}$ I s tímto argumentem lze však polemizovat. Člen voleného orgánu se ve smlouvě o výkonu funkce může zavázat i k povinnostem jdoucím nad (popř. zcela mimo) rámec péče řádného hospodáře. Nebylo by pak logicky konzistentní, aby povinnost k náhradě škody za porušení zákonem dané a nezměnitelné povinnosti jednat s péči ráádného hospodáře byla posuzována optikou odpovědnosti subjektivní, zatímco porušení zcela dobrovolně převzaté povinnosti nad rámec zákona optikou odpovědnosti objektivní?

11 NOVOTNÁ KRTOUŠOVÁ, $c$. $d$.

12 Většina spoluautorů (konkrétně všichni kromě Petra Šuka) zde citovaného komentáře k zákonu o obchodních korporacích, vydaného nakladatelstvím C. H. Beck, se ještě v jeho 2. vydání z roku 2017 klonilo $\mathrm{k}$ zákonné podstatě porušení péče ráádné hospodáře, $\mathrm{v}$ kteréžto věci doznalo 3 . vydání téže publikace $\mathrm{z}$ roku 2020 významného, bohužel nikoli podrobněji odůvodněného, odklonu autorů od tohoto názoru.

13 SVEJKOVSKÝ, J. § 159. In: SVEJKOVSKÝ, J. - DEVEROVÁ, L. Právnické osoby v novém občanském zákoníku. Praha: C. H. Beck, 2013, s. 94.

14 DVOŘÁK, $c . d$.

15 LASÁK, J. § 159. In: LAVICKÝ, P. a kol. Občanský zákonik. I., Obecná část (§ 1-654). Praha: C. H. Beck, 2014, s. 815; shodně také LASÁK, Komentár $k$ § 51.

16 Tamtéž. 


\section{PÉČE ŘÁDNÉHO HOSPODÁŘE JAKO POVINNOST SUI GENERIS}

Obdobně jako Novotná Krtoušová ${ }^{17}$ (viz výše) předkládají Štenglová a Havel ${ }^{18}$ potenciální řešení problému skrze povahu zastoupení právnické osoby členem orgánu, tentokrát však s tím výsledkem, že zastoupení členem orgánu je „na pomezi“ mezi zákonným a smluvním zastoupením. K tomu autoři citují rozsudek Nejvyššího soudu ze dne 23. 7. 2019, sp. zn. 27 Cdo 4593/2017, dle něhož: ,Zastoupení právnické osoby členem statutárního orgánu je zastoupením svého druhu (sui generis), na něž nedopadá ani úprava smluvního zastoupení (\$ 441 až 456 o. z.), ani úprava zastoupení zákonného (\$ 457 až 488 o. z.). "I zde je úskalím redukce problematiky péče řádného hospodáře na zastupování právnické osoby navenek statutárním orgánem. Dle mého názoru obsah citovaného rozsudku zdaleka není možné zobecnit na výkon funkce členů orgánů právnických osob, a už vůbec ne na právní podstatu péče řádného hospodáře. Ostatně, předmětný rozsudek řeší v meritu věci překročení zástupčího oprávnění a o péči řádného hospodáŕe se vůbec nezmiňuje.

Podrobnou a inovativní analýzu problému předkládají Pihera a Havel, ${ }^{19}$ kteř́ jej propojují s pravidly pro správu cizího majetku ve smyslu $§ 1400$ a násl. občanského zákoníku s tím, že člen statutárního orgánu je ve své podstatě správcem cizího majetku, nebot' je mu svěřena působnost rozhodovat o majetku právnické osoby. Dle citovaného článku pak , pravidla správy cizího majetku v občanském zákoníku představuji soubor pravidel, která se uplatňují bez ohledu na povahu konkrétni obligace zakládajici fiduciární vztah, a tedy bez ohledu na právní di̊vod jejího vzniku", ${ }^{20}$ a shodně by tedy měla být nahližena pravidla péče řádného hospodáře. Autoři pak dodávají, že péče ráádného hospodáře je povinností sui generis, jejíž porušení se řídí § 2910 občanského zákoníku, tedy s aplikací subjektivní odpovědnosti. Nedostatkem i této analýzy je náhled problematiky optikou orgánu statutárního, nikoli však optikou také členů jiných volených orgánů právnických osob, kterým není svěřena působnost rozhodovat o majetku právnické osoby, nebo je jim svěřena pouze velmi nepř́mo, např. v tom smyslu, že jako členové kontrolního orgánu kontrolují rozhodování orgánu statutárního.

\section{OSOBNÍ PŮSOBNOST INSTITUTU PÉČE ŘÁDNÉHO HOSPODÁŘE}

S ohledem na shora uvedené považuji za nutné přispět poznámkou týkající se osobní působnosti institutu péče rrádného hospodáře, a to zejména $\mathrm{z}$ důvodu převažujícího zaostření probíhající odborné diskuse na orgán statutární, resp. na členy orgánu s generálním zástupčím oprávněním. Povinnost péče rrádného hospodáře se přitom

\footnotetext{
17 NOVOTNÁ KRTOUŠOVÁ, $c$. $d$.

18 ŠTENGLOVÁ, I. - HAVEL, B. § 51. In: ŠTENGLOVÁ, I. - HAVEL, B. - CILEČEK, F. - KUHN, P. ŠUK, P. Zákon o obchodních korporacích. 3. vyd. Praha: C. H. Beck, 2020, s. 163.

19 PIHERA, V. - HAVEL, B. Povaha funkce a odpovědnost členů orgánů obchodních společností jako východisko racionálního corporate governance. Právní rozhledy. 2019, roč. 27, č. 23-24, s. 836-840.

20 Tamtéž.
} 
vztahuje na všechny členy volených orgánů, tzn. i těch, jimž zákon nepřiznává oprávnění zastupovat právnickou osobu, nebo jej přiznává ve velmi omezeném a specifickém rozsahu, např. procesní zmocnění člena dozorčí rady v řízení proti členu představenstva akciové společnosti ( $\$ 447$ odst. 3 ZOK). V tomto světle potom značně ubývá na síle argumentace, jež právní povahu povinnosti péče řádného hospodáře dovozuje z typu zastoupení (zákonné / smluvní / sui generis). Proto se domnívám, že užití analogie zastoupení právnické osoby není cestou $\mathrm{k}$ řešení problému.

Ve smyslu § 152 odst. 2 občanského zákoníku se ,, členem voleného orgánu "rozumí fyzická osoba, ,která je do funkce volena, jmenována či jinak povolána“. K diskusi o př́padné smluvní povaze povinnosti péče řádného hospodáře je vhodné zmínit právě ty situace, kdy vzniku funkce nepředchází nejen akt „volby“ jakožto projev vůle volitele, nýbrž ani akt „přijeti'“ funkce, jako je tomu u společníkủ veřejné obchodní společnosti a komplementářů komanditní společnosti, v kterýchžto př́ipadech jsou uvedení společníci ex lege statutárními orgány těchto osobních společností bez možnosti funkci odmítnout. ${ }^{21} \mathrm{~K}$ tomu jsou možné přinejmenším dva př́stupy výkladu.

První spočívá v tom, že v důsledku absence aktu přijetí funkce se povinnost péče řádného hospodáře na uvedené společníky osobních společností vůbec nevztahuje, nebot' zkrátka nejsou naplněny všechny hypotézy $§ 159$ odst. 1 občanského zákoníku. Proti tomuto závěru ze systematického hlediska hovoří text $\$ 108 Z^{2 O K}{ }^{22}$ o společnické žalobě odkazující na $\S 53$ odst. 3 ZOK, který výslovně hovoří o újmě způsobené porušením péče rádného hospodáře.

Dle druhého př́istupu se povinnost péče rádného hospodáře vztahuje také na statutární orgány osobních společností. ${ }^{23}$ Založení společnosti, popř. přistoupení k již existující společenské smlouvě, lze vykládat jako autonomní projev vůle, v němž je imanentně obsaženo i „přijetí “ funkce, která v důsledku přistoupení ke společenské smlouvě přistupujícímu vznikne. I tento druhý výklad má však své trhliny, např. v situaci, kdy někdo zdědí podíl společníka veřejné obchodní společnosti, leda bychom projev vůle dědice $\mathrm{k}$ prrijetí dědictví vykládali taktéž jako projev vůle směřující v konečném důsledku ke vzniku funkce. ${ }^{24}$ Ustanovení $§ 117$ ZOK sice umožňuje dědici společenskou smlouvu vypovědět, pak platí fikce, že se společníkem, a tedy ani členem statutárního orgánu, nestal. $\mathrm{V}$ prŕípadě nečinnosti dědice bychom však $\mathrm{k}$ dovození povinnosti péče rádného hospodáře museli konstruovat konkludentní přijetí funkce ze strany dědice. S ohledem na textaci § 546 občanského zákoníku a s ohledem na to, že se nekloním ke smluvní povaze povinnosti péče řádného hospodáře, $\mathrm{v}$ kterémžto př́padě by se aplikovalo ustanovení § 1740 občanského zákoníku, se domnívám, že takové konkludentní přijetí funkce ze strany plně svéprávného dědice lze aplikovat.

21 Ovšem za předpokladu, že splňují podmínky stanovené v § 46 ZOK, a také za předpokladu, že společenská smlouva neurčí, že statutárním orgánem jsou pouze někteří se společníků.

22 Dle mého názoru je toto možné ve smyslu $§ 119$ ZOK přiměřeně aplikovat i na komanditní společnost.

23 Tento názor zastává např. LASÁK, Komentár $k \S 159$, s. 817.

24 Při současném splnění dalších předpokladů, jako je plná svéprávnost, splnění podmínek dle $§ 46$ ZOK, jakožto i absence opačných ujednání ve společenské smlouvě. 


\section{ZÁVĚR}

S ohledem na shora uvedené se kloním k názoru, že povinnost péče řádného hospodáře představuje povinnost ze zákona, na níž se uplatní pravidla subjektivní odpovědnosti za škodu dle $\S 2910$ občanského zákoníku, resp. že péče řádného hospodáře není smluvně založenou povinností, a to z následujících důvodů:

- Kogentnost povinnosti, která nepřipouští smluvní modifikaci. V důsledku limitace autonomie vůle zde absentuje smluvní prvek.

- Na rozdíl od teorie smluvní povahy péče řádného hospodáře zůstává teorie zákonné povinnosti konzistentní i v případech, kdy člen orgánu není př́ímo „Zvolen“ či ,jmenován“, nýbrž je do funkce povolán zákonem.

Pokud jde o koncepci péče řádného hospodáře jakožto povinnosti sui generis, která je prvkem fiduciárního vztahu při správě cizího majetku, pak tato koncepce je funkční a vnitřně konzistentní ve vztahu ke členovi statutárního orgánu právnické osoby, kterému je svěřena působnost rozhodovat o majetku právnické osoby. Tato koncepce by mohla nakonec převážit, podaří-li se její východiska aplikovat také na jiné volené orgány právnických osob.

Za problematické pak považuji dovozování právního důvodu povinnosti péče rádného hospodáře z typu zastoupení právnické osoby členem orgánu. I tento teoretický postup lze poměrně dobře aplikovat na členy statutárního orgánu, nicméně má-li mít skutečně obecnou platnost, bylo by nezbytné jej rozvést také pro jiné, více „exotické“, volené orgány, než je orgán statutární.

JUDr. Tomáš Chrenek, LL.M., MPH

advokát, společník advokátní kanceláře Chrenek - Kotrba

Právnická fakulta Západočeské univerzity v Plzni

chrenek@chrenek-kotrba.cz 